\title{
Solitary fibrofolliculoma of the upper eyelid in a 68-year old female: a case report
}

\author{
Wenqiu Wang and Jinwei Cheng*
}

\begin{abstract}
Background: Fibrofolliculoma is a benign, perifollicular, connective tissue tumor, and it usually arises in the form of multiple lesions, but rarely as a solitary lesion. We report a case of solitary fibrofolliculoma on the eyelid.

Case presentation: A 68-year-old female presented with an asymptomatic mass on the right upper eyelid. The lesion appeared as a flesh-colored, dome-shaped, smooth nodule being the size of $5 \times 5 \times 4 \mathrm{~mm}$, with eyelashes protruding from the surface, and located on the upper lid margin. Shave excision was performed, and the diagnosis of fibrofolliculoma was confirmed finally through histological exam.

Conclusions: Solitary fibrofolliculomas rarely arises on the eyelid. However, it should be suspected when a fleshcolored and doom-shaped lesion of the eyelid is encountered. The benign tumor on the lid margin can be removed by shave biopsy.
\end{abstract}

Keywords: Solitary fibrofolliculoma, Eyelid tumor, Diagnosis, Surgery

\section{Background}

Fibrofolliculoma usually is a clinically asymptomatic multiple connective tissue tumor, appearing perifollicular, skin-colored and located on the head or neck. Multiple fibrofolliculomas generally are inherited as an autosomal dominant trait and share clinical characteristics of Birt-Hogg-Dubé (BHD) syndrome, which is associated with multiple fibrofolliculomas, acrochordons, trichodiscomas, and internal neoplasms [1, 2].

Fibrofolliculoma, rarely presents as a solitary lesion, since being firstly reported in 1984 [3]. Solitary forms are usually unassociated with other cutaneous abnormalities with typically nonhereditary [4]. Only 12 cases have, to date, been previously published in the literature [310]. To our knowledge, our case is the second one reported occurrence on an eyelid [5]. Herein, we presented the clinical features and surgical treatment of a rare solitary fibrofolliculoma located on the upper eyelid of a 68year-old female.

\footnotetext{
* Correspondence: jinwei_cheng@yeah.net

Department of Ophthalmology, Shanghai General Hospital, Shanghai

Jiaotong University School of Medicine, Shanghai 200080, China
}

\section{Case presentation}

A 68-years-old Mongoloid woman presented with an asymptomatic, flesh-colored lesion on the right upper eyelid. The lesion had slowly increased in size over 5 years. No similar lesions were found on other parts of the body. Her medical and family histories were unremarkable, and she had experienced no triggering trauma.

Upon ophthalmologic examination, the protruding lesion was found to be approximately $5 \times 5 \times 4 \mathrm{~mm}$ and located on the upper lid margin (Fig. 1a). Palpation of the lesion did not elicit pain, and the lesion was nonslidable. On the photography of anterior segment, the nodule was verified as flesh-colored, dome-shaped, with eyelashes on the smooth surface, and the lesion located on the anterior lamella of the lid margin, without superficial ulceration and dilated blood vessels. (Fig. 1b). The conjunctiva, cornea, and lens were unremarkable and so as the fundus examination results. Examinations showed that the left eye was normal. The visual acuity of both eyes was $20 / 20$. 

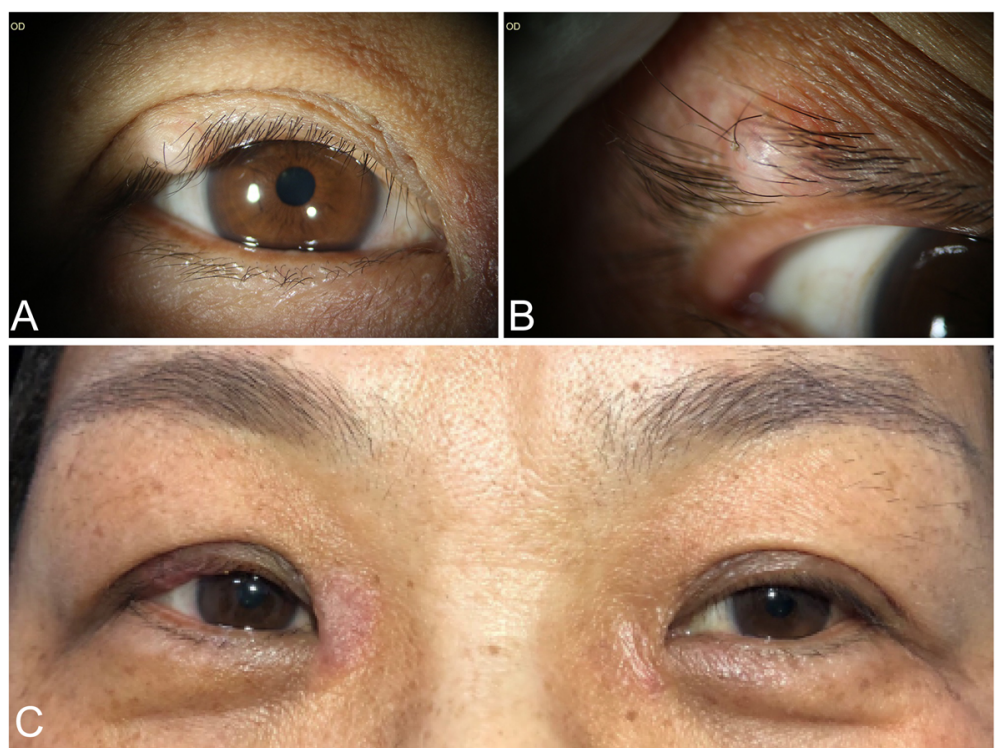

Fig. 1 Preoperative and postoperative appearance of the right eye. a A solitary skin-colored, dome-shaped lesion locates on the right upper eyelid. $\mathbf{b}$ The lesion locates on the anterior lamella of the lid margin, with several eyelashes protruding from its smooth surface. c Two weeks postoperatively, the upper lid maintained its shape

The lesion was removed by shave excision under local anesthesia. The lesion was non-slidable, and it was adherent to the tarsal plate and its covered skin. Anterior lamella of the eyelid was resected with a trigonal wedge, with the removal of $1 \mathrm{~mm}$ of extra tissue from the margin of the lesion, and the thin layer of the tarsal plate. The anterior lamella defect of the upper eyelid was repaired using A-T flap. A gray line split was performed on the cut ends of skin defects, then, the skin defects were sutured directly. We checked the preauricular lymph nodes, and no lymphadenopathy was found. After the operation, the patient was compression bandaged for $24 \mathrm{~h}$.

Histologically examination of the lesion showed a well-defined tumor mass involving a hair follicle, and a proliferation of multiple thin strands of basaloid cells, extending from the central follicle into the surrounding fibrous stroma. The fibrous stroma presented a sharp contrast with the surrounding dermis. Hematoxylineosin stains contained mucin content in the stroma (Fig. 2). The histologic findings were characteristic of fibrofolliculoma.

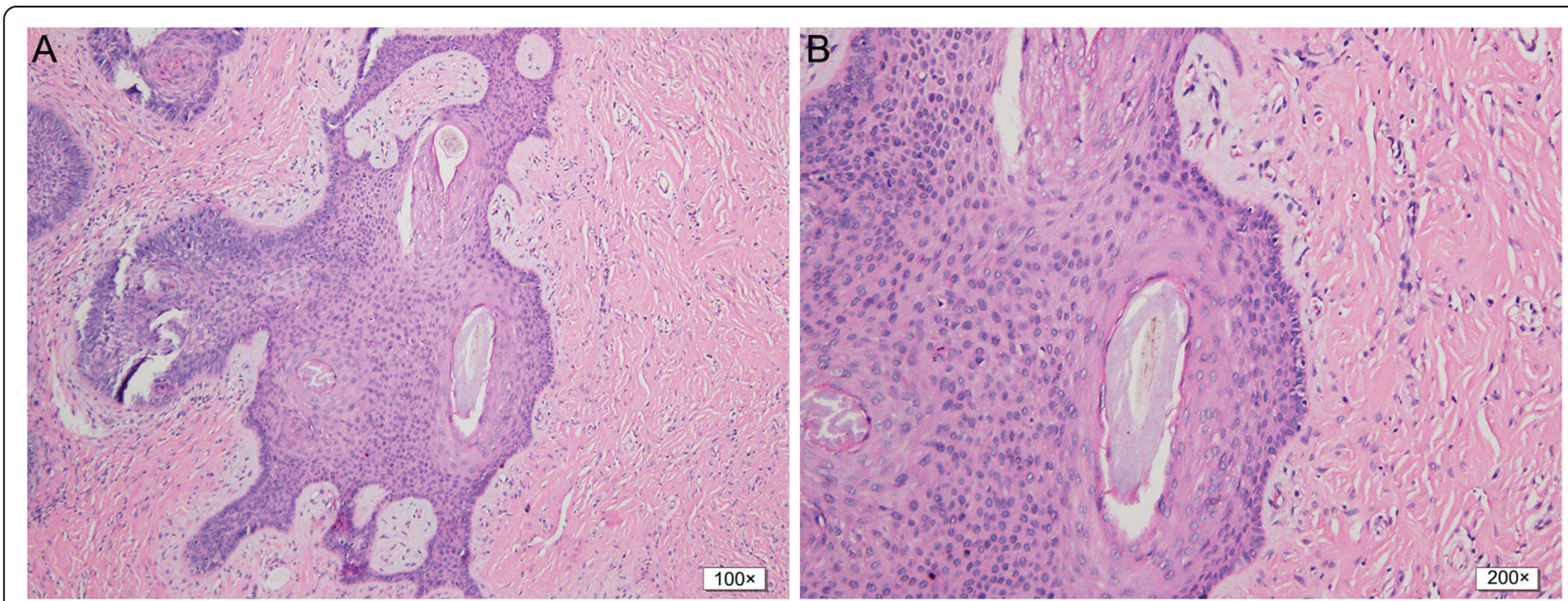

Fig. 2 Histopathological photograph of the solitary fibrofolliculomas. a Low-power photograph (100x) shows the proliferation of multiple thin strands of basaloid cells extending from the central follicle into the surrounding fibrous stroma. b High-power photograph (200x) shows the fibrous stroma contents with mucin, surrounding the hair follicle 
Two weeks after the surgery, the patient had no particular complain. The right upper lid showed almost identical to that of the left (Fig. 1c). During the 3-month follow-up, no signs of recurrence or new lesions appeared.

\section{Discussion and conclusions}

The cases of solitary fibrofolliculoma are extremely rare, since being first reported in 1984 [3]. Only eight prior papers, involving 12 cases, have previously been published worldwide [3-10]. We reviewed the previously published cases and found that most lesions were found on the face, with only 2 around the eyes, one on the eyelid and the other on the eyebrow (Table 1). Among all 13 cases, including the present one, solitary fibrofolliculoma occurs more frequently in women $(5$ men and 8 women), with the mean age at presentation being 51 years. The duration of symptom varying from several months to many years. Solitary fibrofolliculomas share the clinical appearance of multiple fibrofolliculomas, yellowish to flesh-colored, dome-shaped papules.

Histologically, fibrofolliculoma has both an epithelial and a mesenchymal origin, showing distinctive and characteristic features with minor variation [3]. The center of the lesion presents a hair follicle and consists of an expansion of the fibrous root sheath, which typically surrounds the hair follicle, along with proliferating bands or ribbons of perifollicular connective tissue. Cesinaro and coauthors found immunohistochemical expression of factor XIIIa in the bizarre perifollicular cells in a background of CD34-positive spindle cells, which aids for better characterize the nature of the lesion [9].

Table 1 Summary of previous reported cases of solitary fibrofolliculoma

\begin{tabular}{|c|c|c|c|c|c|c|c|c|c|c|c|c|}
\hline Author & Country & Year & $\begin{array}{l}\text { Age } \\
\text { (years) }\end{array}$ & Sex & $\begin{array}{l}\text { Duration } \\
\text { of } \\
\text { symptom }\end{array}$ & Location & $\begin{array}{l}\text { Size of } \\
\text { tumor }\end{array}$ & Mass appearance & $\begin{array}{l}\mathrm{IHC} \\
\text { features }\end{array}$ & $\begin{array}{l}\text { Previous } \\
\text { clinical } \\
\text { diagnosis }\end{array}$ & Treatment & Recurrent \\
\hline $\begin{array}{l}\text { Sohn KM } \\
{[10]}\end{array}$ & Korea & 2018 & 50 & $M$ & 3 years & $\begin{array}{l}\text { right } \\
\text { posterior } \\
\text { auricular } \\
\text { area }\end{array}$ & $10 \times 12 \mathrm{~mm}$ & $\begin{array}{l}\text { slightly pruritic, } \\
\text { flesh-colored }\end{array}$ & & & $\begin{array}{l}\text { shave } \\
\text { biopsy }\end{array}$ & \\
\hline $\begin{array}{l}\text { Criscito } \\
\text { MC [9] }\end{array}$ & US & 2017 & 72 & $\mathrm{~F}$ & $\begin{array}{l}\text { several } \\
\text { years }\end{array}$ & $\begin{array}{l}\text { Left } \\
\text { cheek }\end{array}$ & $\begin{array}{l}\text { 4-mm in } \\
\text { diameter }\end{array}$ & $\begin{array}{l}\text { dome-shaped flesh- } \\
\text { colored papule }\end{array}$ & & & excision & \\
\hline Cho E [8] & Korea & 2012 & 45 & $M$ & 3 years & ear & $12 \times 10 \times 8 \mathrm{~mm}$ & flesh-colored mass & & & $\begin{array}{l}\text { shave } \\
\text { biopsy }\end{array}$ & $\begin{array}{l}\text { No (4 } \\
\text { month } \\
\text { follow- } \\
\text { up) }\end{array}$ \\
\hline $\begin{array}{l}\text { Cesinaro } \\
\text { AM [7] }\end{array}$ & Italy & 2010 & 63 & $\mathrm{~F}$ & $\begin{array}{l}\text { several } \\
\text { months }\end{array}$ & nose & $12 \times 10 \mathrm{~mm}$ & $\begin{array}{l}\text { skin-colored, } \\
\text { smooth surface }\end{array}$ & $\begin{array}{l}\text { co- } \\
\text { expression } \\
\text { of CD34 } \\
\text { and factor } \\
\text { XIlla }\end{array}$ & $\begin{array}{l}\text { basal cell } \\
\text { carcinoma }\end{array}$ & excision & $\begin{array}{l}\text { No }(6 \\
\text { month } \\
\text { follow- } \\
\text { up) }\end{array}$ \\
\hline $\begin{array}{l}\text { Chang } \\
\text { JK [5] }\end{array}$ & Korea & 2007 & 37 & $\mathrm{~F}$ & 1 year & eyelid & $5 \times 5 \mathrm{~mm}$ & $\begin{array}{l}\text { skin-colored bean- } \\
\text { sized mass }\end{array}$ & & chalazion & excision & $\begin{array}{l}\text { No }(2 \\
\text { year } \\
\text { follow- } \\
\text { up) }\end{array}$ \\
\hline $\begin{array}{l}\text { Hong JK } \\
\text { [6] }\end{array}$ & Korea & 1997 & 40 & $\mathrm{~F}$ & 1 year & $\begin{array}{l}\text { left } \\
\text { parietal } \\
\text { scalp } \\
\text { area }\end{array}$ & $7 \times 6 \times 5 \mathrm{~mm}$ & $\begin{array}{l}\text { Skin-to-pink colored } \\
\text { protruding mass } \\
\text { with a shallow } \\
\text { central dell }\end{array}$ & & & excision & \\
\hline \multirow[t]{5}{*}{$\begin{array}{l}\text { Starink } \\
\text { TM [4] }\end{array}$} & US & 1987 & 49 & $M$ & 2 years & chin & $\begin{array}{l}5 \mathrm{~mm} \text { in } \\
\text { diameter }\end{array}$ & Yellowish nodule & & $\begin{array}{l}\text { epiderrnoid } \\
\text { cyst }\end{array}$ & biopsy & \\
\hline & & & 20 & $\mathrm{~F}$ & & nose & & skin-colored papule & & fibroma & & \\
\hline & & & 50 & $M$ & 1 year & $\begin{array}{l}\text { left } \\
\text { cheek }\end{array}$ & & skin-colored papule & & $\begin{array}{l}\text { intradermal } \\
\text { nevus }\end{array}$ & & \\
\hline & & & 60 & $\mathrm{~F}$ & $\begin{array}{l}\text { Several } \\
\text { years }\end{array}$ & ear & $\begin{array}{l}3 \mathrm{~mm} \text { in } \\
\text { diameter }\end{array}$ & $\begin{array}{l}\text { domeshaped } \\
\text { papule with a } \\
\text { central comedolike } \\
\text { opening }\end{array}$ & & $\begin{array}{l}\text { epiderrnoid } \\
\text { cyst }\end{array}$ & & \\
\hline & & & 52 & $M$ & & eyebrow & $6 \times 4 \mathrm{~mm}$ & & & $\begin{array}{l}\text { epidermoid } \\
\text { cyst }\end{array}$ & & \\
\hline $\begin{array}{l}\text { Scully K } \\
\text { [3] }\end{array}$ & Canada & 1984 & 62 & $\mathrm{~F}$ & 4 month & chin & $\begin{array}{l}5 \mathrm{~mm} \text { in } \\
\text { diameter }\end{array}$ & $\begin{array}{l}\text { skin-to-pink-colored, } \\
\text { dome-shaped } \\
\text { papule }\end{array}$ & & & excision & \\
\hline
\end{tabular}


Since solitary fibrofolliculoma is extremely infrequent and definitively diagnosed only by histological results, it can be easily overlooked or clinically misdiagnosed. The 37-year female patient reported by Chang and coauthors was previously misdiagnosed as chalazion and received incision and curettage only. For years, her condition had not improved, recurring several times [5]. Fortunately, fibrofolliculoma rarely develops to malignancy. Once this type of lesion in the eyelid is observed, a diagnosis of fibrofolliculoma should be considered. As the lesion of the presented case was located on the eyelid, it also should be included as a differential diagnosis from malignant conditions such as basal cell carcinoma and squamous cell carcinomas, which are the most common malignant eyelid tumors. Basal cell carcinomas appear as a translucent, waxy papule with a rolled, pearly border, and telangiectasia. As it enlarges, central ulceration usually develops. Squamous cell carcinomas appear as a painless, elevated, nodular, or plaque-like lesion with chronic scaling and fissuring of the skin. The characteristic features of squamous cell carcinomas also include pearly irregular borders and a tendency to develop ulceration with irregular rolled edges.

Sharing the characteristics of BHD syndrome, fibrofolliculoma is considered to be hamartomas, composed of both connective tissue and follicular epithelial components [11]. Most fibrofolliculoma may have some common histogenesis such as abnormal function of hair follicle bulge cells, and differential diagnosis should be considered in the histopathological exam.

Surgical excision is usually chosen for the skin fibrofolliculomas in the first operation for pathological diagnosis. The $\mathrm{CO}_{2}$ laser, or erbium-doped YAG laser, might be a better choice for multiple fibrofolliculomas or recurrent lesions $[12,13]$. Currently, there are no uniform standards for eyelid lesions. Surgical treatment for an eyelid lesion should be individualized based on the size, growth rate, invasion, and interference with eyelid function and aesthetics $[14,15]$. Benign eyelid lesions can be treated with less invasive techniques, such as shaving biopsy, and simple excision. For the benign tumors on lid margin, shave excision including a 1-mm margin of normal tissue should be considered $[16,17]$. Also, postoperative follow-up is necessary to demonstrate early recurrence, and to improve facial appearance as required.

We have presented a rare case of the flesh-colored and doom-shaped lesion arising on the eyelid and show the histologic features of fibrofolliculoma. Although rare, a diagnosis of solitary fibrofolliculoma may be considered when a similar lesion is observed. As the benign tumor on the lid margin, shave excision including a 1-mm margin of normal tissue should be considered. Our report highlights both the clinical and the histopathological features, which are important for appropriate treatment and prognosis prediction.
Abbreviation

BHD syndrome: Birt-Hogg-Dubé syndrome

\section{Acknowledgments}

We thank the patient and her family.

\section{Authors' contributions}

W.W and J.C. Were responsible for the design of the study, surgery for the patient, compiling the data, plus writing and revising the manuscript, which all authors have read and approved.

\section{Funding}

The study was partially supported by Shanghai Pujiang Program

(18PJ1409500), and Natural Science Foundation of Shanghai (18ZR1430300).

Wenqiu Wang is the Principle Investigator of the funds.

Availability of data and materials

More data, if necessary, is available from the corresponding authors upon reasonable request.

\section{Ethics approval and consent to participate}

All procedures performed were in accordance with the ethical standards of the institutional and/or national research committee and with the 1964 Helsinki Declaration and its later amendments or comparable ethical standards. This is a case report, retrospectively describing the course of the diagnostics and therapy, thus does not require the local Bioethical Committee approval.

\section{Consent for publication}

Written informed consent was obtained from the patient for the publication of this report and any accompanying images.

\section{Competing interests}

The authors declare that they have no competing interests.

Received: 24 January 2019 Accepted: 4 March 2020

Published online: 11 March 2020

References

1. Birt AR, Hogg GR, Dubé WJ. Hereditary multiple fibrofolliculomas with trichodiscomas and acrochordons. Arch Dermatol. 1977;113:1674-7.

2. Weintraub R, Pinkus H. Multiple fibrofolliculomas (Birt-Hogg-Dubé) associated with a large connective tissue nevus. J Cutan Pathol. 1977:4:289_ 99.

3. Scully K, Bargman H, Assaad D. Solitary fibrofolliculoma. J Am Acad Dermatol. 1984;11:361-3.

4. Starink TM, Brownstein MH. Fibrofolliculoma: solitary and multiple types. J Am Acad Dermatol. 1987;17:493-6.

5. Chang JK, Lee DC, Chang MH. A solitary fibrofolliculoma in the eyelid. Korean J Ophthalmol. 2007;21:169-71.

6. Hong JK, Yoon DH, Kim TY, Kim HO, Kim CW. A case of solitary fibrofolliculoma. Ann Dermatol. 1997;9:286-8.

7. Cesinaro AM, Rusev BC, Kutzner H. Fibrofolliculoma with ancient/ pseudosarcomatous features. J Cutan Pathol. 2010;37:987-90.

8. Cho E, Lee JD, Cho SH. A solitary fibrofolliculoma on the concha of the ear. Int J Dermatol. 2012;51:616-7.

9. Criscito MC, Mu EW, Meehan SA, Polsky D, Kopeloff I. Dermoscopic features of a solitary fibrofolliculoma on the left cheek. J Am Acad Dermatol. 2017; 76:S8-9.

10. Sohn KM, Woo YJ, Kim JE, Kang H. A solitary nodule on the posterior pinna. Indian J Dermatol Venereol Leprol. 2019;85:111-3.

11. Tellechea O, Cardoso JC, Reis JP, et al. Benign follicular tumors. An Bras Dermatol. 2015:90:780-98.

12. Misago N, Kimura T, Narisawa Y. Fibrofolliculoma/trichodiscoma and fibrous papule (perifollicular fibroma/angiofibroma): a revaluation of the histopathological and immunohistochemical features. J Cutan Pathol. 2009; 36:943-51.

13. Gambichler T, Wolter M, Altmeyer P, Hoffman K. Treatment of Birt-HoggDubé syndrome with erbium: YAG laser. J Am Acad Dermatol. 2000:43:8568. 
14. Cogrel O. CO2 laser treatment of fibrofolliculomas and cutaneous tumors in Birt-Hogg-Dubé syndrome. Ann Dermatol Venereol. 2016;143:230-2.

15. Lo Torto F, Losco L, Bernardini N, et al. Surgical treatment with Locoregional flaps for the eyelid: a review. Biomed Res Int. 2017;2017:6742537.

16. Chang M, Park M, Baek S, Oh JH. The characteristics and second intention healing after shave excision of nevi on the lid margin in east Asians. J Craniofac Surg. 2013;24:e467-70.

17. Dervişoğulları MS, Totan Y, Yıldııım Ü. Isolated Schwannoma of the upper eyelid margin in a 50-year-old male. Turk J Ophthalmol. 2016;46:291-2.

\section{Publisher's Note}

Springer Nature remains neutral with regard to jurisdictional claims in published maps and institutional affiliations.

Ready to submit your research? Choose BMC and benefit from:

- fast, convenient online submission

- thorough peer review by experienced researchers in your field

- rapid publication on acceptance

- support for research data, including large and complex data types

- gold Open Access which fosters wider collaboration and increased citations

- maximum visibility for your research: over $100 \mathrm{M}$ website views per year

At $B M C$, research is always in progress.

Learn more biomedcentral.com/submissions 